\title{
The Effects of Phosphate Solubilizing Rhizobacteria on Soybean (Glycine max. L.) Plants Grown under Insoluble Phosphate Fertilization
}

\author{
Vladimir ROTARU* \\ Institute of Genetics, Physiology and Plant Protection, Chisinau, Republic of Moldova \\ * corresponding author: rotaruvlad@yahoo.com \\ Bulletin UASVM series Agriculture 73(2)/2016 \\ Print ISSN 1843-5246; Electronic ISSN 1843-5386 \\ DOI 10.15835/buasvmcn-agr: 12395
}

\begin{abstract}
The aim of this study was to assess the comparative efficacy of two phosphorus solubilizing rhizobacteria namely Burkholderia cepacia B36 and Enterobacter radicincitans D5/23T combined with insoluble phosphates in soybean (Glycine max. L.). Inoculated plants were grown in sand culture under controlled greenhouse conditions. All the inoculated treatments showed better plant growth and nutrient uptake when compared to uninoculated control. The inoculation with B. cepacia performed better than with E. radicincitans. Phosphorus concentrations in shoots and roots did not change significantly at the early stage of plant growth. However, the bacterial inoculation had better stimulatory effect on phosphorus uptake by soybean fertilized with insoluble phosphates, in particular in treatment with combined application of both bacteria strains.
\end{abstract}

Key words: Glycine max., growth, insoluble phosphate, PGPR

Introduction. Natural rock phosphates and other phosphorus (P) amendments have been recognized as valuable alternatives to $\mathrm{P}$ fertilizers, but nutrient efficiency of these sources is very poor. The assimilation of fixed soil $\mathrm{P}$ as well as hardly soluble phosphates through the use of microorganisms is an option to augment the availability of $\mathrm{P}$ in easily available form by the crops (Poonamgautam et al., 2003). The use of beneficial soil microorganisms could reduce the amount of fertilizer input by increasing the efficiency of nutrient availability and other plant growth promoting activities. It was reported that the bacterial genera Burkholderia (Fankem et al., 2006) and Enterobacter (Kery et al., 2013) are the most powerful P solubilizers. A sand pot experiment was conducted to study the effects of Burkholderia cepacia and Enterobacter radicincitans inoculation on plant growth and nutrition under insoluble $\mathrm{P}$ fertilization.

Aims and Objectives. Plant growth-promoting rhizobacteria (PGPR) can contribute signifi- cantly to plant nutrition and thus may help to reduce chemical inputs in agricultural systems. The objective of the study was to assess the efficacy of two rhizobacteria Burkholderia cepacia B36 and Enterobacter radicincitans D5/23T combined with insoluble phosphates in soybean vegetative growth and nutrition.

Materials and Mmethods. The sand culture experiment was conducted under controlled conditions. The insoluble phosphate $\left(\mathrm{Ca}_{5} \mathrm{P}_{3} \mathrm{HO}_{13}\right)$ was mixed with sand at a dose of $200 \mathrm{mg}$ per kg before planting. Bacteria inoculation was performed by soaking the seedlings with the suspension of Burkholderia cepacia B36 and Enterobacter radicincitans $D 5 / 23 \mathrm{~T}$ separately or their combination. Four treatments were arranged including control insoluble phosphate without inoculation (Ca-P), Ca-P+Burkholderia cepacia $(\mathrm{Ca}-\mathrm{P}+\mathrm{B})$, Ca$\mathrm{P}+$ Enterobacter radicinutians $(\mathrm{Ca}-\mathrm{P}+\mathrm{E})$ and their combination $(\mathrm{Ca}-\mathrm{P}+\mathrm{B}+\mathrm{E})$. The plants were irrigated with Hoagland solution without phosphorus and harvested in the stage of the first true trifo- 


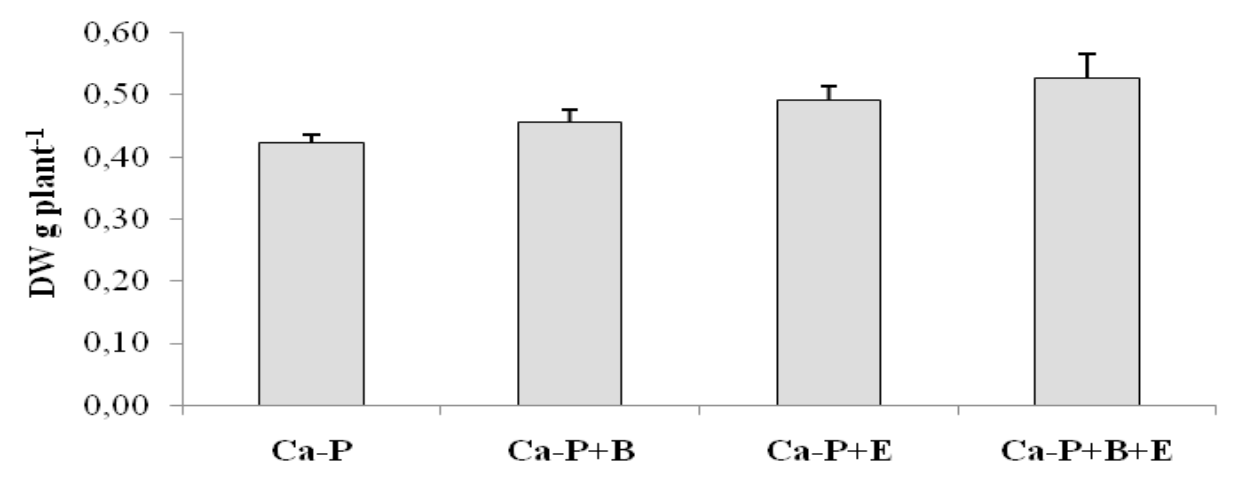

Fig. 1. Interactive effect of PGPR and insoluble $\mathrm{P}(\mathrm{Ca}-\mathrm{P})$ on plant growth. Data are means $\pm \mathrm{SE}$.

Tab. 1. Effect of rhizobacteria on the concentration and uptake of $P$ by soybean plants $( \pm S E)$.

\begin{tabular}{|c|c|c|c|}
\hline Treatments & Shoot ( $\mathrm{mg} \mathrm{P} \mathrm{g}^{-1} \mathrm{DW}$ ) & $\operatorname{Root}\left(\mathrm{mg} \mathrm{P} \mathrm{g}^{-1} \mathrm{DW}\right)$ & $\begin{array}{l}\text { Plant uptake } \\
\left(\text { mg P plant }^{-1}\right)\end{array}$ \\
\hline Ca-P & $2.6 \pm 0.11$ & $3.6 \pm 0.13$ & $1.19 \pm 0.03$ \\
\hline $\mathrm{Ca}-\mathrm{P}+\mathrm{B}$ & $2.4 \pm 0.14$ & $3.8 \pm 0.11$ & $1.39 \pm 0.08$ \\
\hline $\mathrm{Ca}-\mathrm{P}+\mathrm{E}$ & $2.4 \pm 0.15$ & $3.1 \pm 0.13$ & $1.29 \pm 0.06$ \\
\hline $\mathrm{Ca}-\mathrm{P}+\mathrm{E}+\mathrm{B}$ & $2.3 \pm 0.10$ & $3.7 \pm 0.11$ & $1.50 \pm 0.05$ \\
\hline
\end{tabular}

liate leaf. Phosphorus concentrations in the samples were analyzed calorimetrically after staining with ammonium-molybdate-vanadate solution. P uptake per pot was calculated by multiplying biomass (g) with P concentration ( $\mathrm{mg} \mathrm{g}^{-1}$ ).

Results and Discussion. It is known that to improve the growth of crop during their early development period is very important for plant performance in particular under low soil fertility. Experimental results demonstrated that the shoots growth displayed an early positive response to inoculation compared to roots growth. The shoot biomass increased by $22-24 \%$ in comparison to control plants (Fig. 1). Probably, the phytohormones activities of isolates were displayed faster to promote shoot growth, rather than the solubilisation ability of strains, because there were not significant changes in $\mathrm{P}$ concentration in plant tissues at this early stage of growth (Tab. 1). Similar effects by rhizobacteria administration were obtained by Defreitas and Germida (1992) that in soil of low fertility Pseudomonas significantly enhanced wheat growth. There were not significant increases in both shoot and root $\mathrm{P}$ concentrations at early growth period but there was an increase in phosphorus acquisition of plants with the use of inoculation application. The results revealed that the use of rhizobacteria increased the $\mathrm{P}$ use efficiency compared to control plants.

Conclusion. Combined use of strains B. cepacia and E. radicincitans proved to be superior to their separate application on growth and phosphorus nutrition of soybean plants.

\section{REFERENCES}

1. Defreitas JR, Germida JJ (1992). Growth promotion of winter wheat fluorescent Pseudomonas under growth chamber conditions. Soil Biol. Biochem. 24, 1127-1135.

2. Fankem H, Nwaga D, Deubel A, Dieng L, Merbach W, Etoa FX (2006). Occurrence and functioning of phosphate solubilizing microorganisms from oil palm tree (Elaeis guineensis) rhizosphere in Cameroon. African J. Biotech. 5:2450-2460.

3. Krey T, Vassilev N, Baum C, Eichler-Löbermann B (2013). Effects of long-term phosphorus application and plantgrowth promoting rhizobacteria on maize phosphorus nutrition under field conditions. Eur J Soil Biol 55:124130.

4. Poonamgautam AK, Agnihotri LM (2003). Effect of phosphorus rate and Pseudomonas species in combination with Bradyrhizobium japonicum and farmyard manure on seed yield and yield attributes of soybean (Glycine max). Indian J. Agric. Sci., 73: 426-428. 